\section{Section Editor}

Mitchell S.V. Elkind, MD, MS

Human Sinha, MD, DM Dheeraj Khurana, MD, DM

Address correspondence and reprint requests to Dr. Dheeraj Khurana, Department of Neurology, PGIMER, Chandigarh 160012, India dherajk@yahoo.com

\title{
Teaching NeuroImages: \\ A case of partial oculomotor palsy
}

Figure 1 Examination of conjugate extraocular movements showing right adduction palsy and right partial ptosis
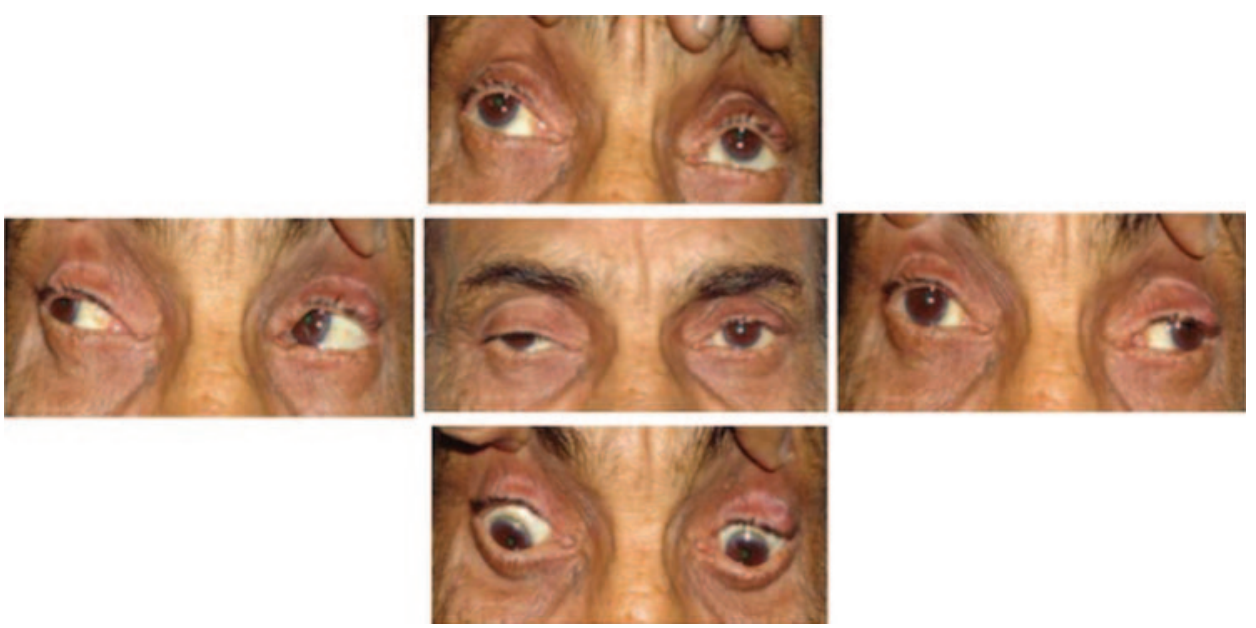

A 68-year-old hypertensive man presented with binocular horizontal diplopia associated with drooping of right eyelid. Examination revealed medial rectus palsy, noncorrectable ptosis of the right eye (figure 1), normal pupils, and no long tract signs. Brain MRI showed a hyperintense T2 signal in the dorsal midbrain and diffusion restriction on diffusion-weighted imaging with corresponding reduced apparent diffusion coefficient (figure 2, A, C, and D). At 2 months, diplopia and ptosis improved significantly. Individual third nerve fascicles in the ventral mesencephalon have a topographic arrangement (figure 2B). ${ }^{1}$ The medial rectus fascicle occupies the intermediate position between superior rectus and levator palpebrae superioris. ${ }^{1,2}$

\section{AUTHOR CONTRIBUTIONS}

Dr. Sinha: drafting of manuscript, data acquisition. Dr. Khurana: drafting and revising of manuscript, concept of the manuscript.

\section{REFERENCES}

1. Castro O, Johnson LN, Mamourian AC. Isolated inferior oblique paresis from brain-stem infarction: perspective on oculomotor fascicular organization in the ventral midbrain tegmentum. Arch Neurol 1990;47:235-237.

2. Johnson LN, Castro O. Monocular elevation paresis and incomplete ptosis due to midbrain infarction involving the fascicular segment of the oculomotor nerve. J Clin Neuroophthalmol 1992;12:73. 


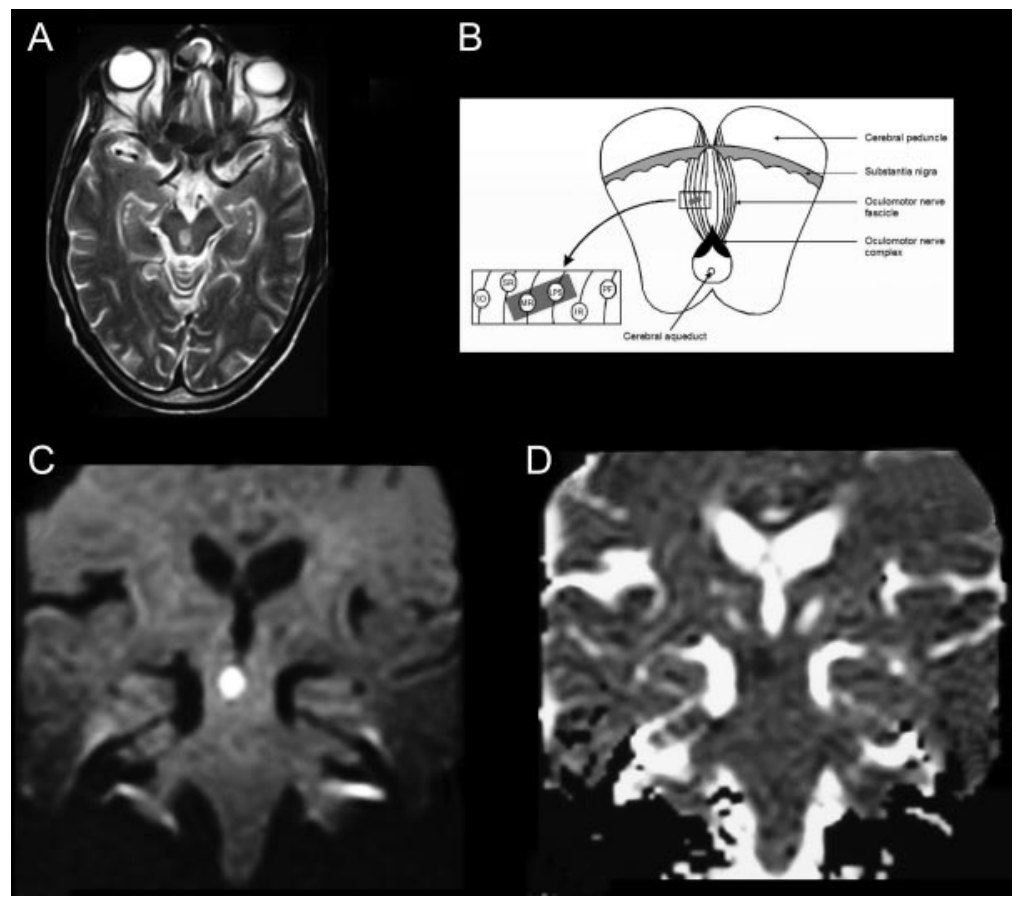

(A) Brain MRI shows hyperintense signal in the dorsal midbrain on the right side on axial T2-weighted image and (B) schematic representation of the oculomotor nerve fascicles in the midbrain with the arrangement of various fibers in the oculomotor nerve fascicle: IO = inferior oblique; IR = inferior rectus; LPS = levator palpebrae superioris; $M R=$ medial rectus; PF = pupillary fibers; SR = superior rectus. (C, D) Diffusion-weighted imaging (coronal) with reduced apparent diffusion coefficient on the corresponding site. 


\section{Neurology}

\section{Teaching NeuroImages: A case of partial oculomotor palsy Human Sinha and Dheeraj Khurana \\ Neurology 2011;77; e150-e151 \\ DOI 10.1212/WNL.0b013e31823d7674}

\section{This information is current as of December 12, 2011}

\section{Updated Information \&} Services

References

Subspecialty Collections

Permissions \& Licensing

Reprints including high resolution figures, can be found at: http://n.neurology.org/content/77/24/e150.full

This article cites 2 articles, 0 of which you can access for free at: http://n.neurology.org/content/77/24/e150.full\#ref-list-1

This article, along with others on similar topics, appears in the following collection(s):

All Cerebrovascular disease/Stroke

http://n.neurology.org/cgi/collection/all_cerebrovascular_disease_strok

e

Diplopia (double vision)

http://n.neurology.org/cgi/collection/diplopia_double_vision

DWI

http://n.neurology.org/cgi/collection/dwi

Infarction

http://n.neurology.org/cgi/collection/infarction

Information about reproducing this article in parts (figures,tables) or in its entirety can be found online at:

http://www.neurology.org/about/about_the_journal\#permissions

Information about ordering reprints can be found online:

http://n.neurology.org/subscribers/advertise

Neurology ${ }^{\circledR}$ is the official journal of the American Academy of Neurology. Published continuously since 1951, it is now a weekly with 48 issues per year. Copyright Copyright (? 2011 by AAN Enterprises, Inc.. All rights reserved. Print ISSN: 0028-3878. Online ISSN: 1526-632X.

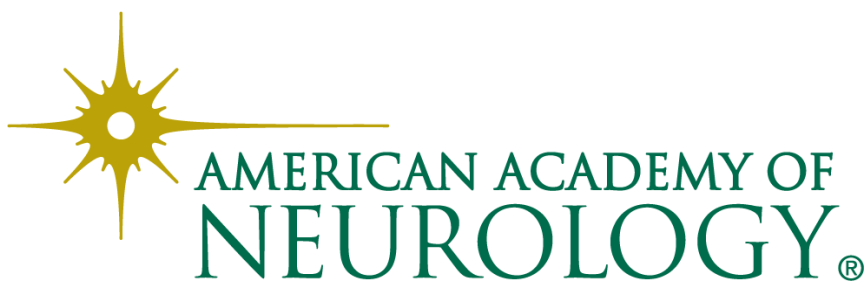

